This item was submitted to Loughborough's Research Repository by the author.

Items in Figshare are protected by copyright, with all rights reserved, unless otherwise indicated.

\title{
Impact of gasoline direct injection fuel injector hole geometry on spray characteristics under flash boiling and ambient conditions
}

PLEASE CITE THE PUBLISHED VERSION

https://doi.org/10.1016/j.fuel.2018.11.143

\section{PUBLISHER}

(C) Elsevier

\section{VERSION}

AM (Accepted Manuscript)

\section{PUBLISHER STATEMENT}

This paper was accepted for publication in the journal Fuel and the definitive published version is available at https://doi.org/10.1016/j.fuel.2018.11.143

\section{LICENCE}

CC BY-NC-ND 4.0

\section{REPOSITORY RECORD}

Jiang, Changzhao, Matthew C. Parker, J. Helie, Adrian Spencer, Colin Garner, and Graham Wigley. 2018. "Impact of Gasoline Direct Injection Fuel Injector Hole Geometry on Spray Characteristics Under Flash Boiling and Ambient Conditions". figshare. https://hdl.handle.net/2134/36441. 


\title{
Impact of Gasoline Direct Injection fuel injector hole geometry on spray characteristics under flash boiling and ambient conditions
}

\author{
Changzhao Jiang, Matthew C. Parker, Jerome Helie*, Adrian Spencer, Colin P. Garner, Graham \\ Wigley \\ Loughborough University, UK \\ *: Continental Automotive SAS, Toulouse, France. \\ Correspondent Author: A.Spencer@lboro.ac.uk
}

\begin{abstract}
The effect of injector nozzle design on the Gasoline Direct Injection (GDI) fuel spray characteristics under atmospheric and flash boiling conditions was investigated using Phase Doppler Anemometry (PDA) measurements. To understand the impact of hole diameter and conicity, experiments were conducted on two bespoke 3-hole injectors in a pressure and temperature controlled constant volume chamber and in the open air. The measurements were taken radially outward from the injector axis to the outer extent of the plume at distances of $15 \mathrm{~mm}, 25 \mathrm{~mm}$ and $40 \mathrm{~mm}$ from the injector tip.
\end{abstract}

Observations of the influence of surrounding gas and temperature conditions and hole design on the injector spray performance were made. Under non-flash boiling conditions, it was found that the injection pressure dictates the length of the spray penetration before collapse occurs, with an increase in pressure resulting in an increase in this length. Comparison of mean velocity and droplet diameter data are also made to understand the performance under flash boiling conditions. Results show that, under flash boiling conditions, the droplet velocity significantly increases while the droplet size reduces. More importantly, it is found that the impact of the flash boiling environment on sprays of different hole geometries is different. Some hole designs offer more resistance against spray collapse. It was found that the mid-sized of the three hole diameters tested here was found to produce a spray that more readily collapsed than that of the smaller or larger hole diameters. In addition, it was found that under flash boiling conditions, the convergent hole had a greater propensity to exhibit spray collapse. 
Key words: Phase Doppler Anemometry measurement, Flash boiling, Hole geometry, Spray characteristics, Fuel.

\section{Introduction}

In recent years, gasoline direct injection (GDI) technology has been widely adopted in spark ignition engines due to its advantages compared to port fuel injection (PFI). It provides the opportunity for faster transients and better cold start response, improved fuel economy and reduced tailpipe emissions $[1][2][3]$. In order to realise this potential in a GDI engine, understanding and control of the spray characteristics in a complex engine cylinder environment is crucial [4][5][6]. For the fuel to fully mix with air, the injection event of a GDI engine is usually during the intake stroke, where the in-cylinder pressure is sub-atmospheric and the fuel can rapidly reach a temperature of $400 \mathrm{~K}$ to 530 $\mathrm{K}$ upon injection, [7]. This means that there is a high likelihood of the spray being introduced into an environment that promotes flash boiling. Flash boiling occurs when a liquid is rapidly depressurised sufficiently below its saturation or vapour pressure and becomes superheated, quickly changing state to achieve thermal equilibrium. The saturation pressure of a liquid is a function of its temperature, therefore an increase in the ambient temperature and/or a decrease in the surrounding pressure increases the likelihood of flash boiling occurring when a liquid is injected into a hot and low-pressure environment (e.g. during the intake stroke of internal combustion engine).

The level of fuel superheating during actual operation of a vehicle can be significant. Real gasolines are blends of hundreds of hydrocarbons, with a boiling point range of typically 303-473K, dependent on the exact composition. Kraemer et al. [8] computed the occurrence of flash boiling during normalised car testing cycles, based upon representative fuel injection timing, engine cylinder pressure and fuel temperature for a for a mid-range $1360 \mathrm{~kg}$ car fitted with a 4 cylinder, $1.4 \mathrm{l}, 91 \mathrm{~kW}$ engine. They found that the engine performance was partly influenced by superheating during most of the regulated drive cycles. In the case of the New European Driving Cycle (NEDC) they found an influence on emissions from fuel superheating for $95 \%$ of the test duration and, in the case of testing 
based upon the outline of the, then, forthcoming Real Driving Emissions (RDE) addition to the NEDC, some influence was apparent up to $99 \%$ of the test duration.

The occurrence of flash boiling can significantly affect the spray shape and subsequently the performance of a typical automotive multi-hole fuel injector system used in high pressure GDI systems [9][10][11][12][13][14]. An example is given in Figure 1, showing how dramatically an injector's spray morphology is influenced by the conditions of the air region into which it was injected. Some research reports that the smaller droplet breakup and rapid evaporation of fuel undergoing flash boiling would lead to an improved mixing process and a more homogenous air-fuel mixture [13][15][16]. However, it is demonstrated in other studies [10][17] that, when the surrounding pressure and temperature conditions are in the superheated region and far away from the fuel's vapour pressure curve, the multi-jet spray morphology can be significantly influenced by jet-to-jet interaction which can even lead to a full collapse of the jets towards the spray centre, as shown in Figure 1(b). Such a collapse can significantly reduce the spray angle, reducing the usage of available air for mixing and, additionally, can increase the spray penetration, potentially leading to greater levels of piston and combustion chamber wall impingement. Both consequences can potentially generate unacceptably high levels of both particulate and gaseous emissions such as CO and HC. For these reasons, an understanding of the factors affecting the occurrence of spray collapse and its impact under modern Gasoline Direct Injection (GDI) operating conditions is important. 


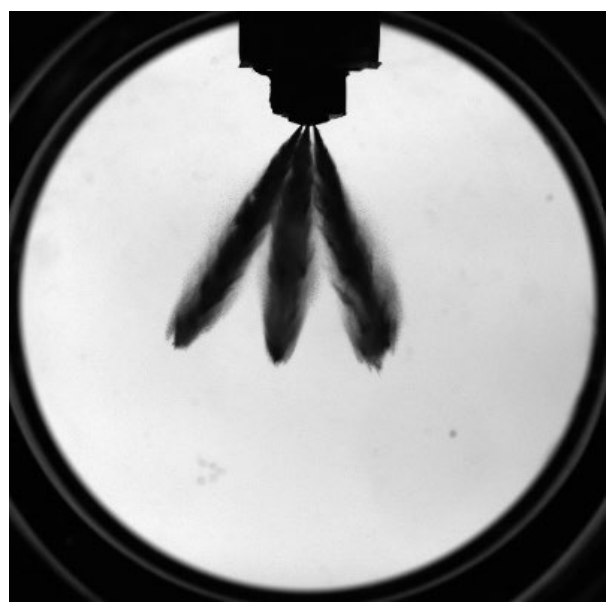

(a)

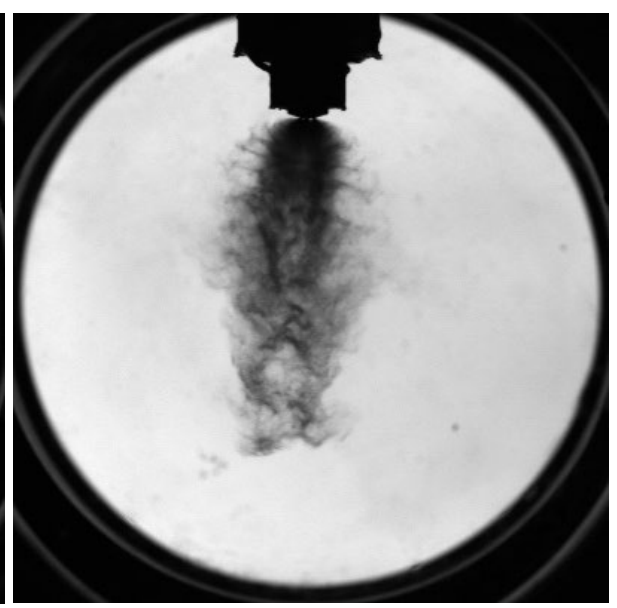

(b)

Figure 1 -Spray morphology of a GDI injector at $0.7 \mathrm{~ms}$ after start of injection: formed spray (a), collapsed spray under flash boiling condition (b).

The actual process of spray collapse is a complex interaction of a number of factors, such as jet-to-jet proximity, the dynamics of the spray development, air entrainment and vapour release to the surroundings [13][18][19][20]. In addition to the engine operating conditions, the fuel injector design governs many of these processes in part and must be understood and characterised. Previous work has been conducted addressing these issues [21][22][23][24][25] and reported in the literature but there are still many phenomena to be understood. For example, the influence of the fuel injector hole length and diameter, as well as the ratio of the two parameters under flash boiling conditions is still not fully understood. Yildiz et al. [26] concluded that there were no measureable effects on the spray from changes in nozzle diameter whilst Vu and Aguilar [27] argued that larger diameters promote a better liquid fuel breakup under flash boiling conditions.

In the case of modelling of flash boiling, additional experimental data is needed to aid understanding of the impact of hole geometry and improve the validity of the simplifications of the phenomenon which are made. Typical models are axisymmetric and based on an extension of two-phase pipe [13][27] or cavitation flows [13] or are semi-empirical [17]; the accuracy of these approaches must be more fully validated. In addition, the simplification of the operating conditions and complexity of 
the exact fuel composition can affect the model accuracy significantly. Detailed spray measurements close to the injector nozzle exit, under representative operating conditions are therefore required to better understand the flash boiling of fuel sprays and to improve their modelling.

In conclusion, the flash boiling and spray collapse phenomenon of the spray should be better understood due to their importance to GDI engine performance and emissions. In recent years, a significant amount of research has been conducted in order to understand the impact of flash boiling on spray characteristics [9-12,14,28-42]. However, the impact of injector design under flash boiling conditions has been rarely addressed. Therefore, the focus of this paper is on understanding whether geometrical features of the hole design impact the spray behaviour similarly under both atmospheric and flash boiling conditions. The flash boiling phenomenon is investigated using Phase Doppler Anemometry (PDA) measurement on the spray in open air as well as in a pressure vessel, where the initial surrounding environmental conditions can be controlled.

\section{Instrumentation and Test Methodology}

In this study, Phase Doppler Anemometry (PDA) is used to understand the microscopic spray behaviour of different fuel injector hole features under both atmospheric and flash boiling conditions. This section introduces the PDA measurement technique, the spray characterisation rig, the fuel injector used and the test methodology.

\subsection{The Phase Doppler Anemometry technique}

The PDA technique is a laser based diagnostic method that provides point measurements of droplet size and velocity in a spray[43]. The system used in this study was a two-velocity component, high power system, developed specifically during previous research to capture measurements in dense automotive fuel sprays, where light obscuration is high. The system layout is illustrated in Figure 2 and described in detail in [44] and [45]. An upgraded signal processor was used here compared to 
the aforementioned references, since the injection pressure in this study, coupled with the subatmospheric back pressure, resulted in peak spray velocities exceeding the measurement range of the previous Dantec 58N50 processor. The Dantec P80 processor was therefore used in preference, with a frequency of $90 \mathrm{MHz}$ as opposed to $45 \mathrm{MHz}$ of the previous system, in turn increasing the vertical direction velocity range upper limit from $108 \mathrm{~ms}^{-1}$ to $294 \mathrm{~ms}^{-1}$. Despite the improved signal processing hardware, the data rates experienced could still be low and this necessitated the capture of 120 injection events in order to ensure a sufficient number of fuel droplets were measured to obtain statistically robust validated data.

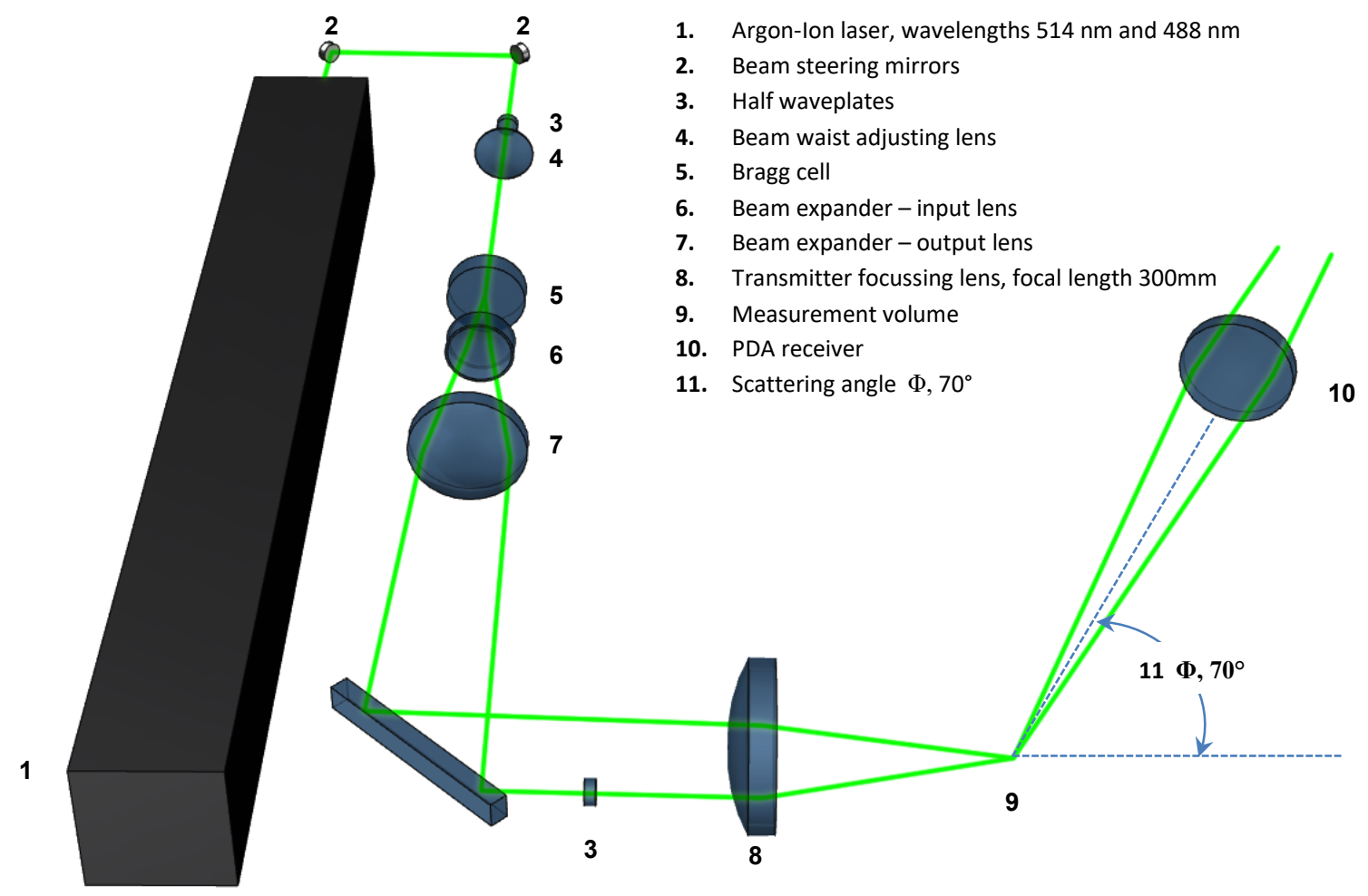

Figure 2 - Schematic diagram of the PDA system used..

Measurements were made along transverse axes at three positions, located at different distances along an axis parallel to the injector's vertical axis, as illustrated in Figure 3(a), these are indicated as red lines across the plume. Measurements made at $15 \mathrm{~mm}$ and $25 \mathrm{~mm}$ were carried out in the pressure cell under temperature and pressure-controlled conditions; these locations were largely 
driven by the space restrictions of the pressure vessel in which the measurements were made. At atmospheric back pressure, the droplet velocity was slower but the spray denser than at subatmospheric conditions and thus light obscuration from the plume was greater. Because of the level of obscuration, the measurements in atmospheric conditions were therefore made at $40 \mathrm{~mm}$ distance from the injector tip, where the spray density was reduced, thus ensuring the quality of the data captured was high. The impact of measurement distance from injector tip on the data quality is discussed more fully in Jiang et al. [46], whilst more details of the test configuration will be discussed later in this paper. Once obtained, PDA droplet data was analysed using an in-house Matlab code, producing results of the type illustrated in Figure 3(b), where an example of droplet velocity versus time is shown. The analysis region was chosen to be solely in the steady state period of an injection to exclude the impact of the transients at the start and end of the injection event. This duration is more important because most liquid mass is injected in this period. This method can also avoid the bias towards the unsteady injection period caused by lower PDA data collection rates during the main spray period than the PDA data collection rate in the opening and closing period, where lower spray density increases the data validation fraction. The procedure has been explained into detail in many former publications [47-49] using the same setup and former generation of GDI injectors.

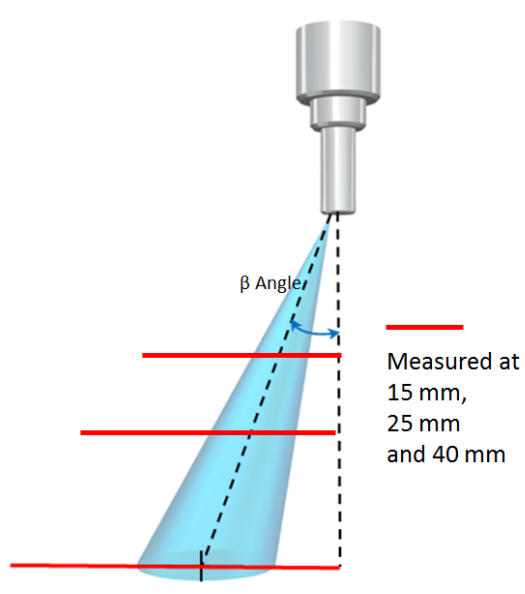

(a)

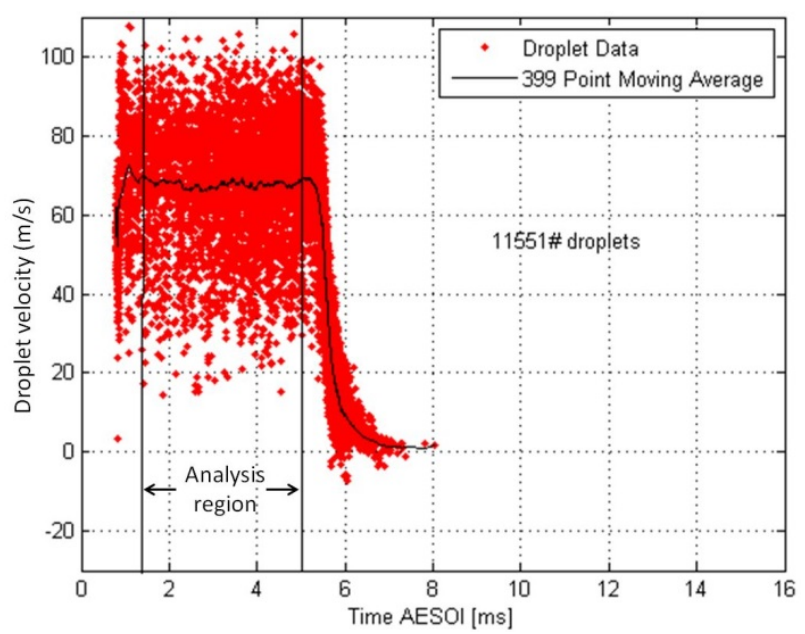

(b)

Figure 3 -PDA measurement locations (a) and typical drop velocity time history (b). 


\section{$\underline{2.2 \text { Test Conditions and Injector Configuration }}$}

This investigation was conducted using two bespoke research GDI fuel injectors; one with divergent and one with convergent holes, both of which have been the subject of simulation studies, previously reported [50]. Each injector featured three holes circumferentially spaced by $120^{\circ}$ about the injector's central axis (see Figure 4). This arrangement of three holes was specifically intended to tailor the injector for optical measurement, by allowing sufficient isolation of plumes for the delivery of laser illumination and imaging. Having fewer injection holes also helped reduce the potential influence of plume-to-plume interaction, minimising the change in an individual injector hole performance under flash boiling conditions. The convergence or divergence of the injector holes tested was quantified by the term Conicity Factor, CF. This term is derived from the hole inlet diameter at the injector sac volume $D_{i}$, the hole outlet diameter at the engine cylinder volume, $D_{a}$ and the hole length, I, as illustrated in Figure 4 and defined as Equation 1.

$$
C F=\frac{100\left(D_{i}-D_{a}\right)}{l}
$$
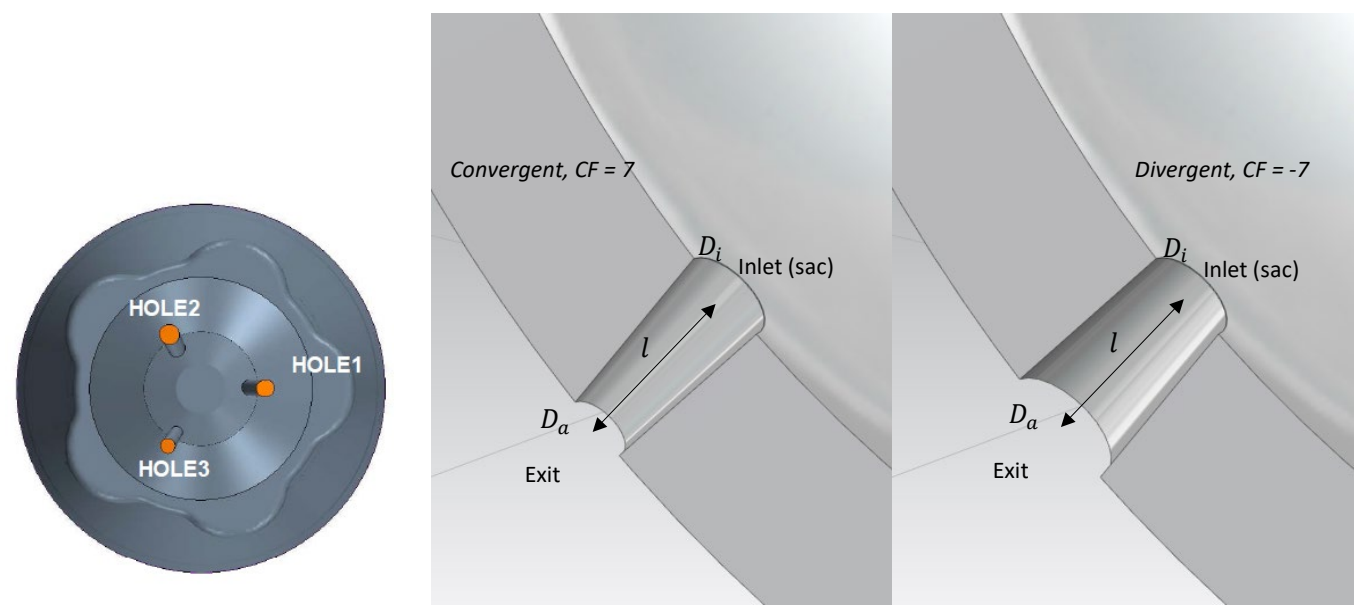

Figure 4 - The bespoke 3 hole research fuel injector used during the tests reported here (left) and an illustration of convergent and divergent holes (right).

A summary of the injector features and other test configurations are presented later in Table 1 . The injectors were tested on Loughborough University's spray characterisation rig, which allowed the PDA technique to be applied to the fuel spray. The injectors were configured to spray into an aluminium pressure vessel whose initial temperature and internal pressure were controlled to 
simulate various engine operating conditions. Quartz windows for optical access allow PDA to be performed on the spray within this vessel. The pressure vessel was controlled by a National Instruments USB controller and its pressure set to the desired level between a nominal vacuum and $1 \mathrm{MPa}$, either by introducing pressurised nitrogen to raise the pressure or using a vacuum pump to reduce the pressure below the atmospheric level.

\section{$\underline{2.3 \text { Test fuel }}$}

Euro 5 reference gasoline RF-02-08 was used for the tests reported here, which has the evaporation characteristic plotted as a black solid line in Figure 5. The shaded regions illustrate the movement of the evaporation curve when the backpressure increases or decreases. In this study, the back pressure is always equal to or less than $101 \mathrm{kPa}$ so the evaporation line will always be moving within the upper (red) region above the black plotted line.

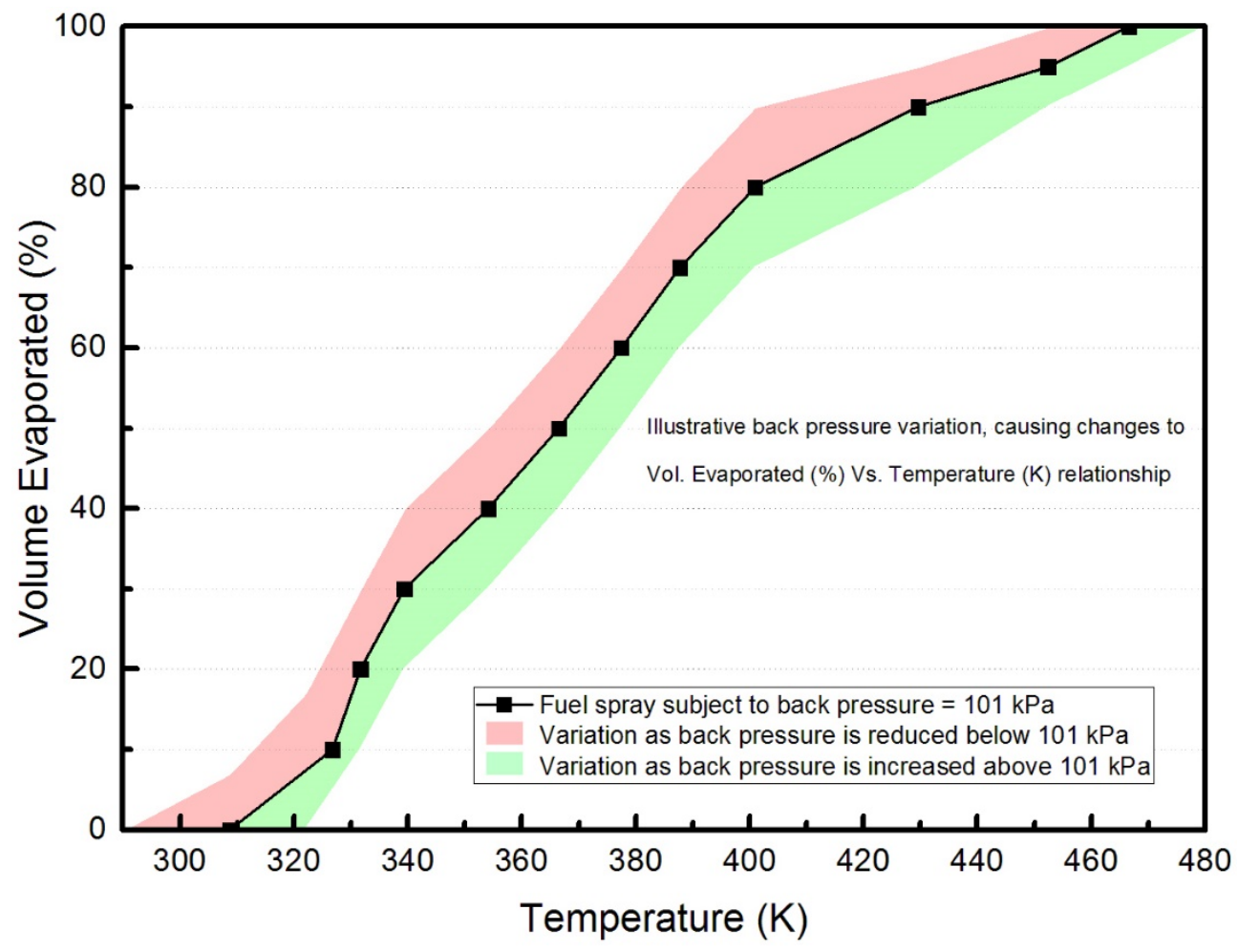

Figure 5 - The evaporation characteristic of RF-02-08 Euro 5 reference gasoline. 


\section{$\underline{2.4 \text { Test configuration }}$}

The results presented in this work span a range of ambient temperature and pressures, along with injector geometrical variations, to investigate the droplet size distribution and velocity behaviour under both ambient laboratory conditions as well as pressure and temperature-controlled conditions, which were set to promote flash boiling. Results are taken at a baseline condition of 20 $\mathrm{MPa}$ injection pressure, $100 \mathrm{kPa}$ abs back pressure and $298 \mathrm{~K}$ cell temperature for three holes of various $L / D$ ratios and both converging and diverging hole conicities. Results in which temperature, injection pressure, back pressure, hole conicity and L/D ratio were varied are then presented, primarily at flash boiling conditions, to compare with the baseline data and allow the influence of these parameters to be compared. The testing reported in this paper was conducted in one of two test configurations; the parameters consistent across both configurations are detailed in Table 1 and those which differed are listed in Table 2.

Table 1 - Common test configuration parameters.

\begin{tabular}{|lr|}
\hline Parameter & \multicolumn{2}{c|}{ Value } \\
\hline Fuel type & Euro 5 Reference Gasoline RF-02-08 \\
Injection pulse width & $5 \mathrm{~ms}$ \\
Injection frequency & $2 \mathrm{~Hz}$ \\
Number of injections & 120 \\
measured & 7 \\
Convergent hole $C F$ & -7 \\
Divergent hole $C F$ & $2.5,2.1$ and 1.75 \\
Hole length/diameter & \\
ratios & \\
\hline
\end{tabular}

Table 2 - Test configuration parameters varied across the testing programme.

\begin{tabular}{|lcc|}
\hline Parameter & Configuration A & Configuration B \\
\hline Air temperature & Ambient $(\sim 298 \mathrm{~K})$ & $\sim 363 \mathrm{~K}$ \\
Back pressure & $\begin{array}{c}\text { Atmospheric } \\
(\sim 101 \mathrm{kPA})\end{array}$ & 30,50 and $100 \mathrm{kPa}$, \\
$\begin{array}{l}\text { Injection } \\
\text { pressure }\end{array}$ & $20 \mathrm{MPa}$ & 10 and/or $20 \mathrm{MPa}$ \\
$\begin{array}{l}\text { Fuel temperature } \\
\text { PDA }\end{array}$ & $\sim 303 \mathrm{~K}$ & $\sim 363 \mathrm{~K}$ \\
$\begin{array}{l}\text { measurement } \\
\text { vertical distance } \\
\text { from injector tip }\end{array}$ & $40 \mathrm{~mm}$ & 15 and/or $25 \mathrm{~mm}$ \\
\hline
\end{tabular}


In each test presented in the results section, PDA measurements were made at a number of locations across the width of the spray plume and were taken from a steady-state portion of the injection event, when the mass flow rate exiting the nozzle is approximately constant.

\section{Results and discussion}

This section presents and describes the droplet size and velocity measurements gathered during testing. The results illustrate investigations into the influence of injector design features and operational parameters upon the spray characteristics produced by a GDI injector. The effect of back pressure on the structure of the injector spray is first reported, which helped define the environmental conditions used in the rest of the study. Following this first section, the effects of several injector design parameters upon spray deformation are considered; hole diameter, conicity and injection pressure.

\subsection{The Influence of Back Pressure on Injector Spray Deformation}

The flash boiling point of the RF-02-08 Euro 5 reference gasoline used in this study can be estimated by considering the relationship between fuel volume evaporated and temperature, presented previously in Figure 5. The real-world behaviour of a fuel spray, however, is highly dynamic, such that the conditions leading to spray collapse in an engine cannot be entirely predicted based upon the theoretical evaporation characteristics. This study aimed to experimentally investigate the fuel spray behaviour under simulated engine conditions to provide additional understanding and validation data for computer-based modelling tools.

The test was setup with the base configuration as detailed in Table 1 and with the additional specific configuration B of Table 2. Results for the convergent $2.1 \mathrm{~L} / \mathrm{D}$ ratio hole injecting into a range of back pressures $(30,50$ and $100 \mathrm{kPa})$ at $90^{\circ} \mathrm{C}$ ambient temperature are presented in Figure 6 . Measurements of mean droplet diameter and both horizontal and vertical components of the droplet velocity taken across the fuel plume width are also presented in Figure 6 . The plots indicate 
that a reduction in applied back pressure brought about a reduction in mean droplet size and an increase in both components of mean droplet velocity. The peak velocity magnitude for the $100 \mathrm{kPa}$, $50 \mathrm{kPa}$ and $30 \mathrm{kPa}$ cases were $96 \mathrm{~ms}^{-1}, 126 \mathrm{~ms}^{-1}$ and $153 \mathrm{~ms}^{-1}$ respectively. This increase in velocity is to be expected because of the accompanying decrease in the air density which comes from the reduction in the applied back pressure but the flash boiling itself could also potentially contribute [51][48]. The increase of droplet velocity increases the Weber number of the spray, resulting in the observed greater level of breakup leading to a smaller droplet size, e.g. reducing from 8 to $5 \mu \mathrm{m}$ at the distance of $16 \mathrm{~mm}$ from the injector tip as the back pressure is reduced from $100 \mathrm{kPa}$ to $30 \mathrm{kPa}$.

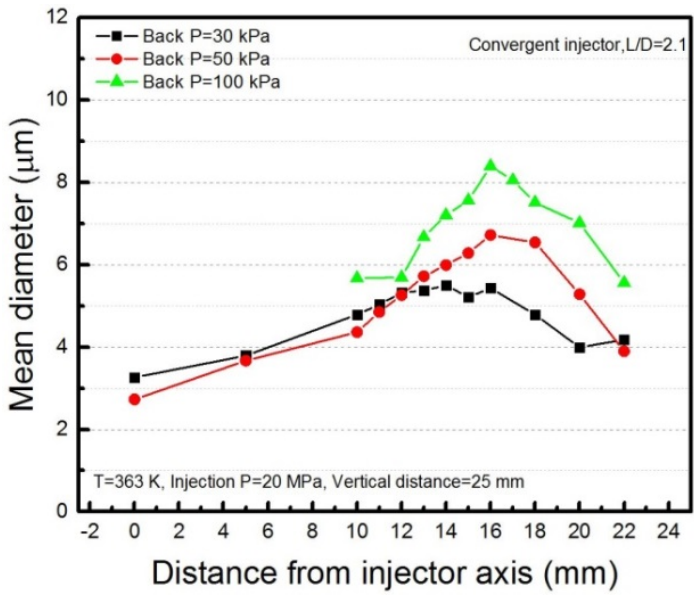

(a)

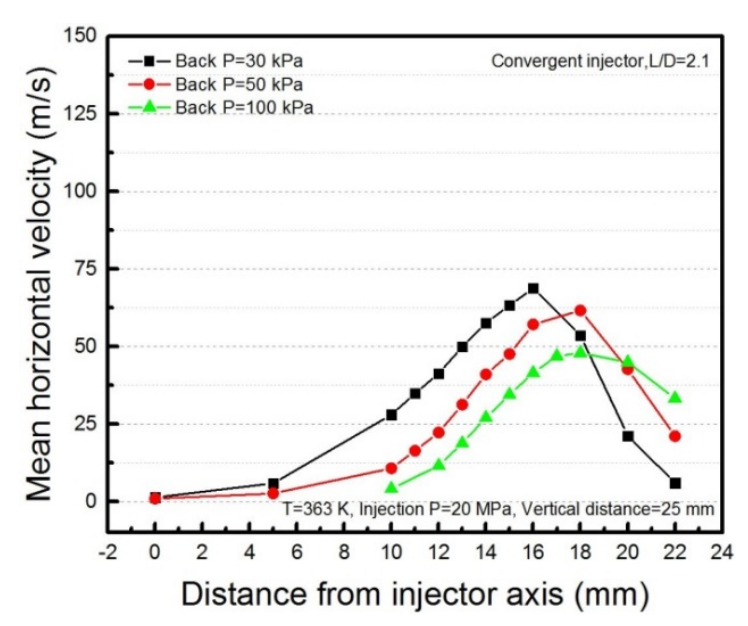

(c)

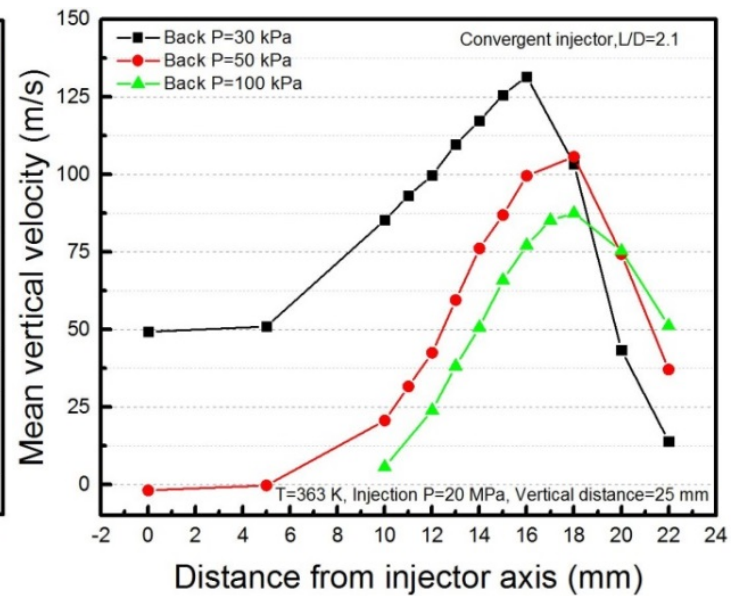

(b)

Figure 6 - Droplet mean diameter (a), mean vertical velocity (b) and mean horizontal velocity (c) for spray at $90^{\circ} \mathrm{C}$ temperature and subject to different back pressures. The measurements are made at $25 \mathrm{~mm}$ from the injector tip. 


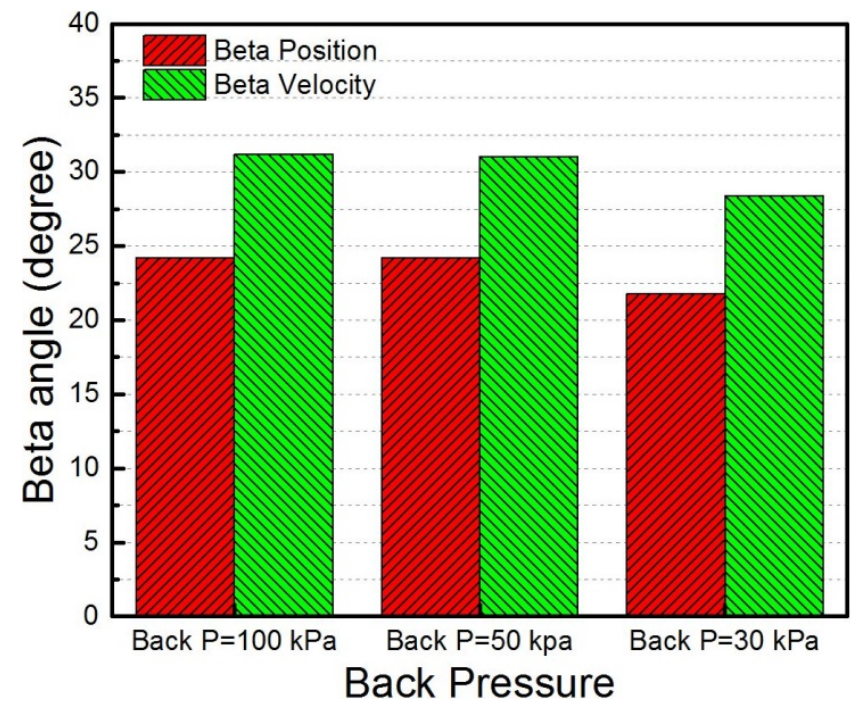

Figure 7 - Angle from the velocity peak position (beta_position) and from the peak velocity direction (beta_velocity) extracted from Figure 6.

The plume-direction (vertical) average velocity profile across the plume is closely linked with the shape of the plume. Shown in Figure $6 \mathrm{~b}$, the peak velocity on the velocity profile is taken to represent the centre location of the plume. As the measurement point of the PDA system moves out of the plume centre to either side of the plume, the average velocity decreases. If the velocity becomes zero, it is thought the measurement point is at or near the boundary of the plume. Thus, the centre and the width of the plume can be extracted from these average plume direction velocity profiles. The velocity profiles in Figure 6 show that the location of both the highest horizontal and vertical velocity components move towards the injector axis as the applied back pressure was decreased, indicating that the spray plume was also deformed towards the injector axis. This is confirmed in Figure 7, where the most significant change in angle per unit back pressure can be seen to have been between $50 \mathrm{kPa}$ and $30 \mathrm{kPa}$. Additionally, a significantly higher level of vertical velocity is apparent within $10 \mathrm{~mm}$ of the injector axis in the $30 \mathrm{kPa}$ case, which also suggests that this case experienced the most significant level of flash boiling. A significantly higher level of vertical velocity is apparent at the $30 \mathrm{kPa}$ (lowest) back pressure case in comparison to the other plots, which would suggest that spray collapse is only apparent at the $30 \mathrm{kPa}$ back pressure and $363 \mathrm{~K}$ temperature condition. 
In response to the initial observations presented in this section, the remainder of this paper will investigate GDI fuel sprays at both the $30 \mathrm{kPa}$ back pressure, $363 \mathrm{~K}$ condition, that are found to lead to significant spray collapse at $20 \mathrm{MPa}$ injection pressure, and also under ambient conditions (293 K temperature, $100 \mathrm{kPa}$ back pressure) where no collapse is seen. Features of injector hole design as well as the injection pressure will be studied by making measurements to understand the impact of the injector configuration on spray behaviour under atmospheric and flash boiling conditions.

\subsection{Impact of hole conicity on spray characteristics}

It has previously been reported that hole conicity affects the droplet size and velocity distributions measured in a GDI fuel spray, as well as the spray plume width [46]. Since, as with all manufactured parts, the hole is produced within a tolerance, it is important to understand the potential impact of the conicity levels that might arise in manufacture across a range of operating conditions. The test was configured as per the base configuration in Table 1 and with results were gathered under both the configurations of Table 2 .

Figure $8(a)$ compares the mean average droplet diameter across the spray plume for both the convergent and divergent hole profiles under atmospheric conditions, where the divergent hole profile produced the smallest droplet size except for at the centre of the plume, where the droplet size from each hole was comparable. The velocity profiles of the spray, also presented in Figure 8 suggest that the plume of the divergent hole was narrower than the convergent profile hole (Figure 8(b)) and that there was a difference in the angles of the plumes from each injector, indicated by the difference in peak location in Figure 8(c). In addition, the divergent hole produced a higher peak velocity in both measurement directions. It might be expected that the convergent hole would produce the highest exit velocity due to the flow acceleration caused by the area reduction of the hole, so the divergent hole velocity result is unexpected. A possible explanation for this observation is that divergent hole flow was influenced by flow detachment at the nozzle inlet whereby the flow area was not expanding with the geometrical expansion of the hole, but rather a pronounced vena- 
contracta effect, stabilised by the air backflow from the nozzle exit plane, caused the mixed fuel-air flow to accelerate and stay separated from the wall of the nozzle.

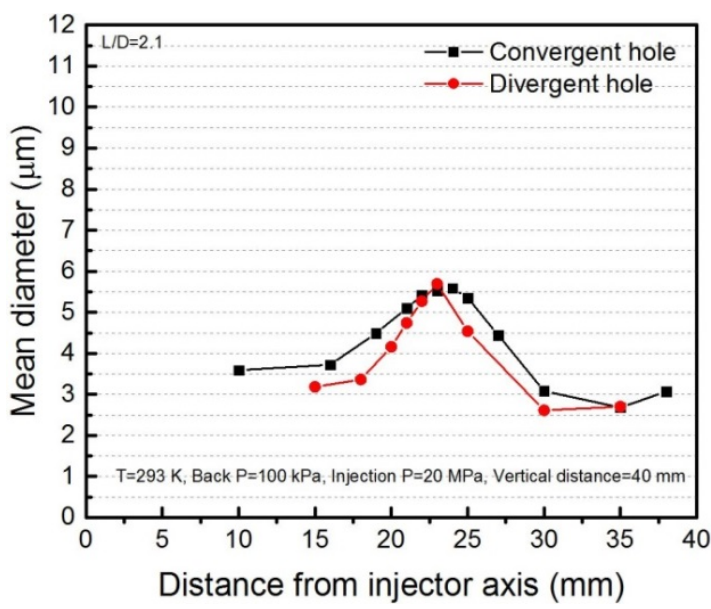

(a)

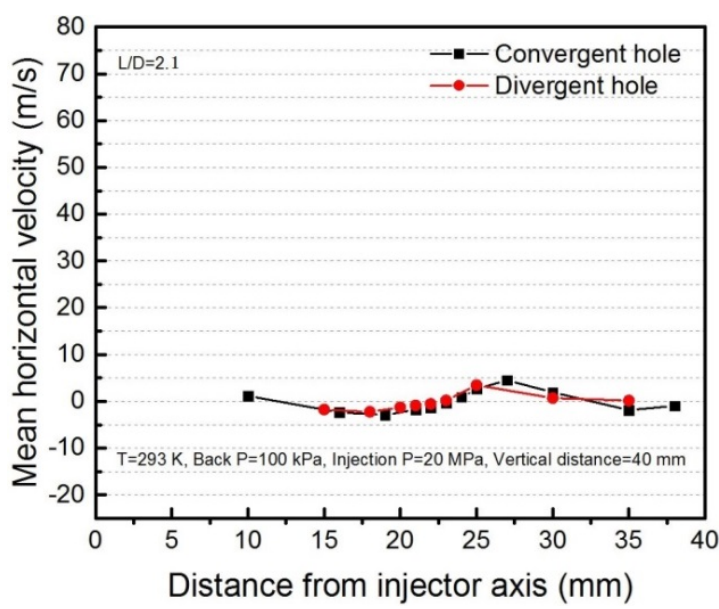

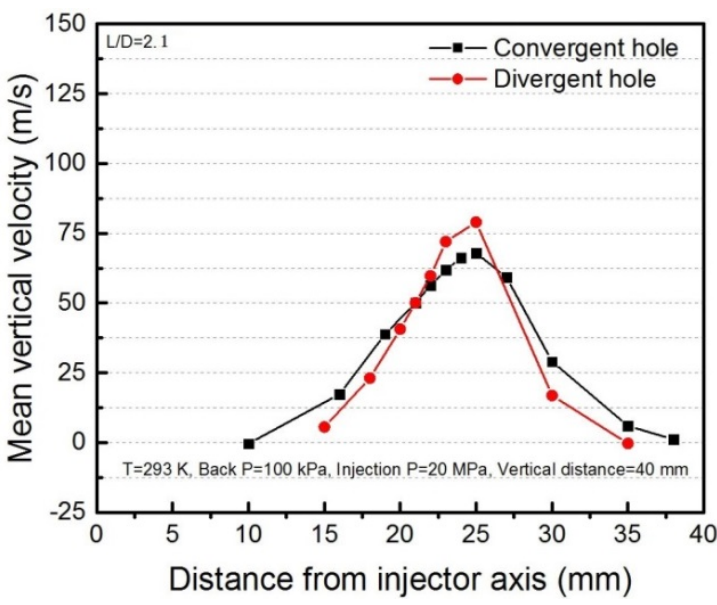

(b)

(c)

Figure 8 - Droplet mean diameter (a), mean vertical velocity (b) and mean horizontal velocity for spray under ambient temperature and pressure measured at $\mathbf{4 0} \mathrm{mm}$ from the injector tip

In contrast to the previous figure, Figure 9 shows the droplet diameter and velocity characteristics measured for the two hole profiles under flash boiling as opposed to atmospheric conditions. When considering the results presented in Figure 9(a), it can be seen that the droplet size measured for the divergent hole case was larger than for the convergent hole. This observation under flash boiling conditions ( $30 \mathrm{kPa}$ back pressure, $363 \mathrm{~K}$ ambient temperature, $20 \mathrm{MPa}$ injection pressure) presented here is opposite to that for the atmospheric condition, where the droplet size of the divergent hole was generally smaller than the convergent hole. This change in droplet size distribution can likely be 
attributed to the different hole geometry's resistance to flash boiling, which can be seen to be different. The velocity data under flash boiling conditions clearly indicates this; it can be seen in frames (b) and (c) of Figure 9 that there was a significant difference between the velocity profiles for each hole conicity between $0 \mathrm{~mm}$ and $12 \mathrm{~mm}$ across the spray; the magnitude of this discrepancy and the fact that it would not be expected to see a significant velocity in the region between $0 \mathrm{~mm}$ and $5 \mathrm{~mm}$ indicates that there had been collapse of the spray in the case of the convergent hole. The presence of a significant number of droplets in the $0 \mathrm{~mm}$ to $5 \mathrm{~mm}$ region, which allowed the recorded velocity signals to be captured, were brought about by collapse of the spray due to the falling pressure as the flow accelerated through the converging hole to conserve mass flow. Conversely, the pressure recovery experienced by the decelerating flow in the divergent hole helped to prevent the spray from collapsing. The collapse of the spray of the convergent hole led to a significant reduction of the droplet size, thus a lower average droplet size is observed.

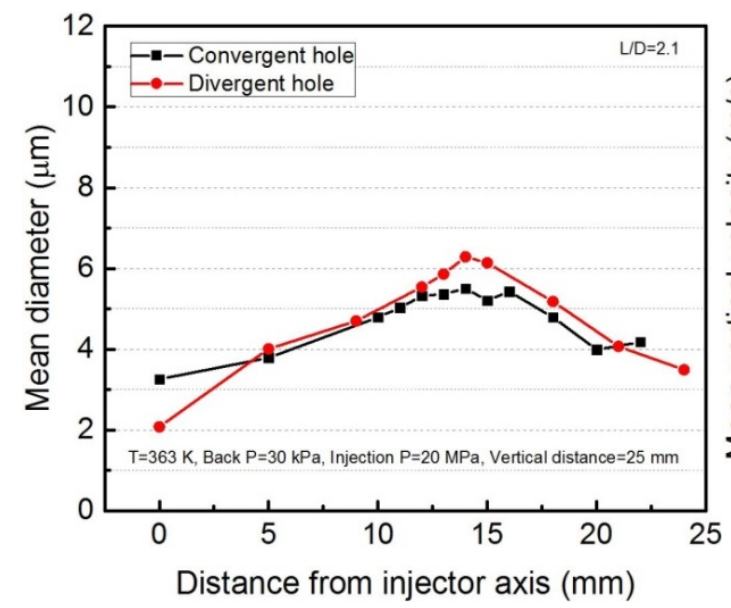

(a)

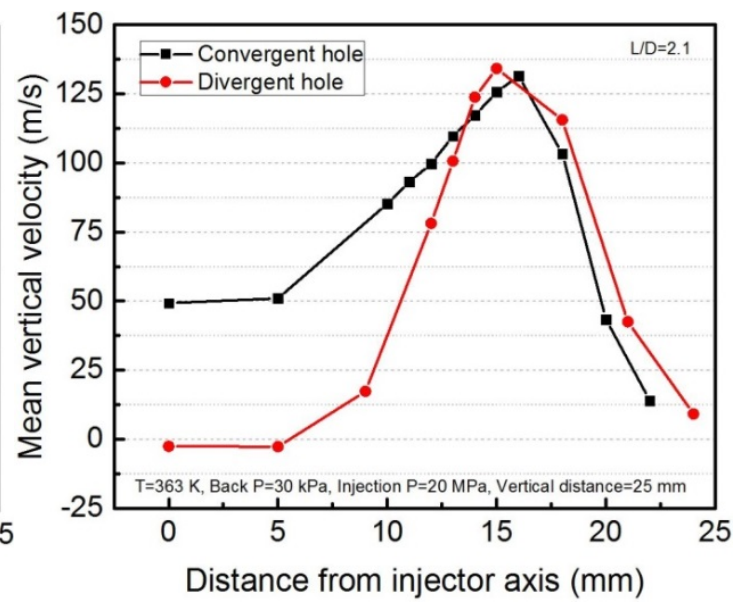

(b) 


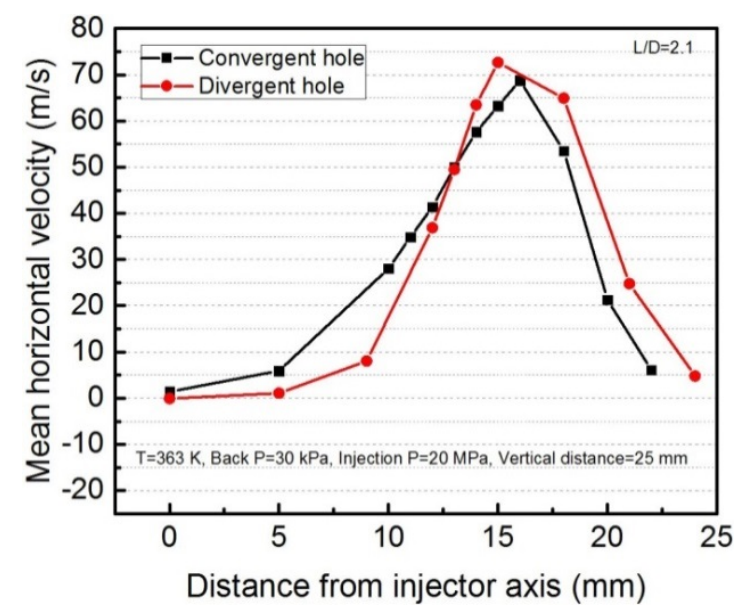

(c)

Figure 9 - Droplet mean diameter (a), mean vertical velocity (b) and mean horizontal velocity for spray under flash boiling conditions measured at $25 \mathrm{~mm}$ from the injector tip

\subsection{Impact of injection pressure on spray characteristics at different distances}

Increasing injection pressure is typically seen as a means of reducing the fuel droplet size in the spray event [52] and a fundamental understanding of the spray that arises at different injection pressures is therefore extremely significant. To this end, an investigation was conducted during this work to study the impact of the injection pressure on spray breakup under flash boiling conditions. The test was configured as per the base configuration in Table 1 and with configuration B of Table 2. Figure 10 and Figure 11 present the PDA measurements made at the two test fuel injection pressures (10 MPa and $20 \mathrm{MPa}$ ) and two vertical distances from the injector nozzle tip (15 and 25 $\mathrm{mm}$ respectively) under flash boiling conditions of $363 \mathrm{~K}$ temperature and $30 \mathrm{kPa}$ back pressure. Figure 10(a) shows that at $15 \mathrm{~mm}$ vertical height the average droplet diameter for $20 \mathrm{MPa}$ injection pressure was actually generally higher than that of the $10 \mathrm{MPa}$ injection pressure test. However, Figure 11(a) illustrates the trend changing at $25 \mathrm{~mm}$, such that the droplet diameter during the 20 $\mathrm{MPa}$ injection pressure test was lower than that of $10 \mathrm{MPa}$ injection pressure test. The switch between the higher pressure case having the larger droplet size at $15 \mathrm{~mm}$ and the smaller at $25 \mathrm{~mm}$ was due to differing distances at which the spray started to collapse. Evidence could be seen from Figure $10(\mathrm{~b})$, which the average velocity for $10 \mathrm{MPa}$ plume at the injector axis is around $50 \mathrm{~m} / \mathrm{s}$ whereas the average velocity for $20 \mathrm{MPa}$ plume at the injector axis is only $10 \mathrm{~m} / \mathrm{s}$. This means that 
the spray plume for $10 \mathrm{MPa}$ case has already collapsed whereas the spray plume for $20 \mathrm{MPa}$ has not at a vertical distance of $15 \mathrm{~mm}$. Thus average droplet size for the $10 \mathrm{MPa}$ case is smaller although its injection pressure is lower due to the impact of spray collapse (higher evaporation) on it. 


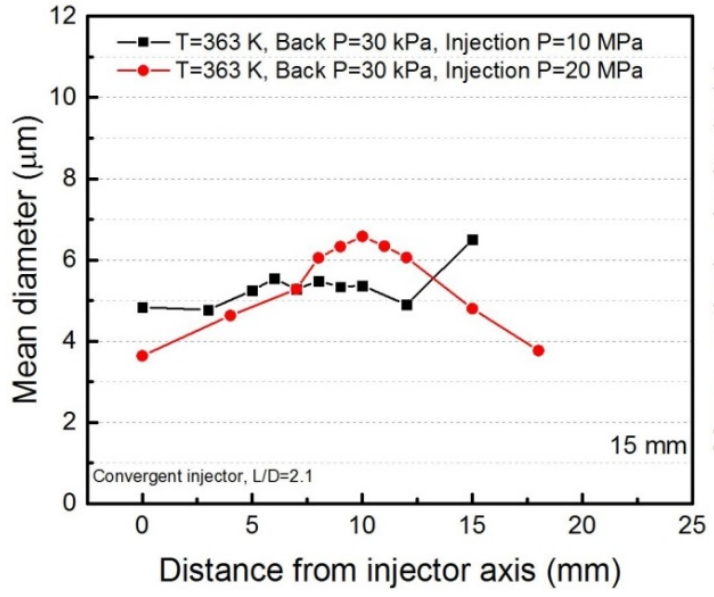

(a)

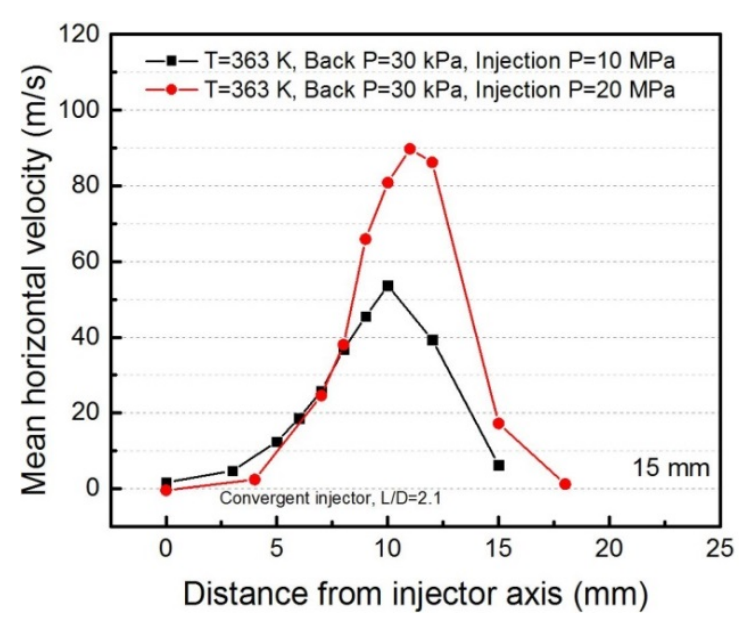

(c)

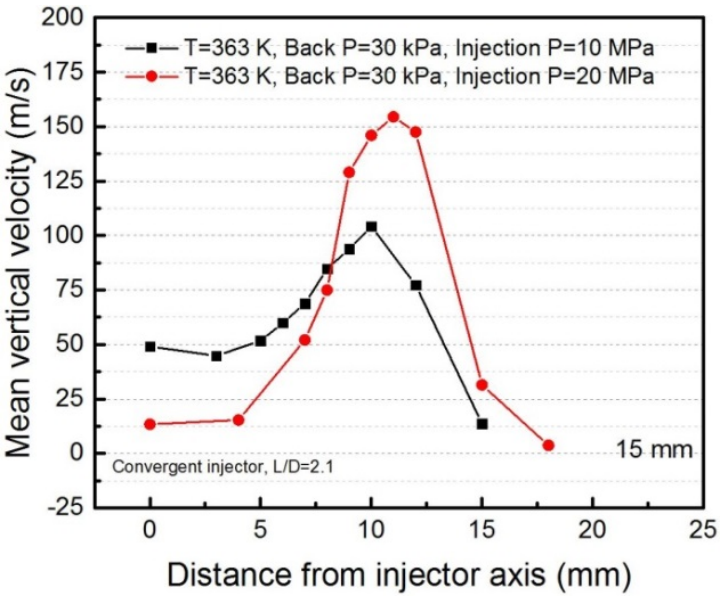

(b)

Figure 10 - Spray characteristics of convergent injector measured at a distance of $15 \mathrm{~mm}$ 


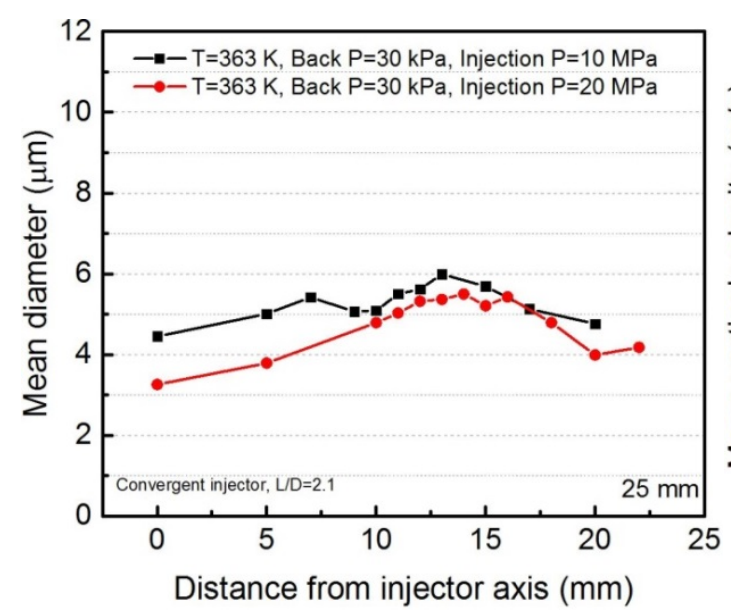

(a)

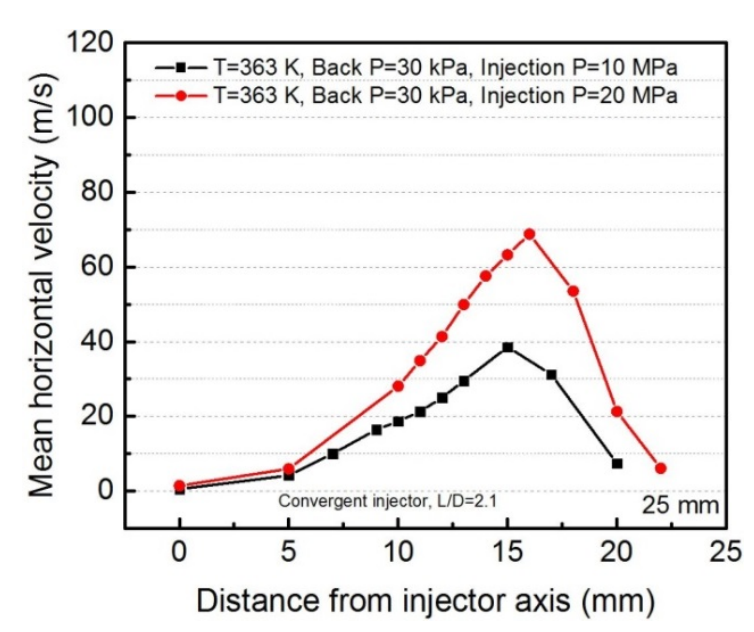

(c)

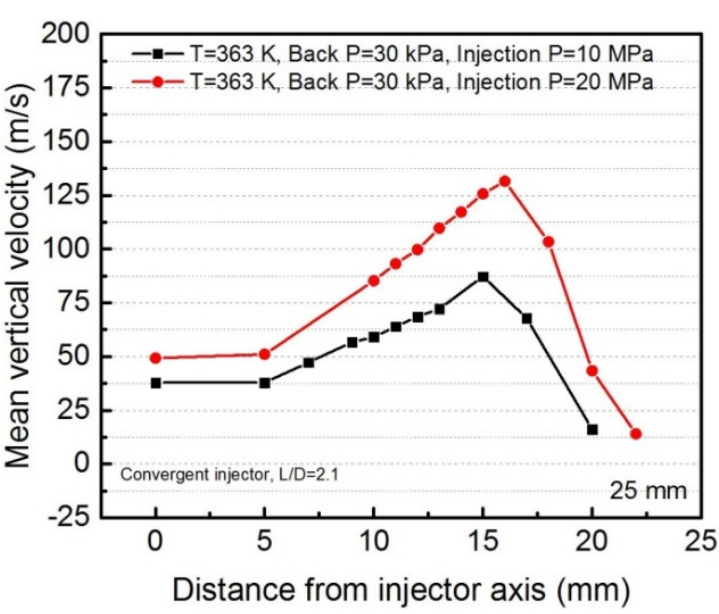

(b)

Figure 11 - Spray characteristics of convergent injector measured at a distance of $25 \mathrm{~mm}$

The profile of velocity in the vertical direction taken across the spray is a good indicator of the spray plume shape, as the peripheral measurements of velocity indicate the outer most presence of fuel droplets (necessary to produce a measurement), whilst the velocity peak indicates the plume centre position. From Figure 10 (b) it is apparent at a distance of $15 \mathrm{~mm}$ from the injector that the $20 \mathrm{MPa}$ injection pressure case has shown less sign of spray collapse as the velocity in the region near to the injector central axis is close to zero. At this same location, the $10 \mathrm{MPa}$ injection pressure case demonstrated distinct signs of spray collapse as there was a significant vertical velocity measured in the region between 0 and $5 \mathrm{~mm}$ of Figure 10(b), indicating an inward collapse of the spray. Collapse of the spray for the $10 \mathrm{MPa}$ case led to better break-up of its fuel droplets, thus a lower mean diameter which was seen at $15 \mathrm{~mm}$ distance compared to the $20 \mathrm{MPa}$ case. At $25 \mathrm{~mm}$ from the tip of 
the injector nozzle, spray collapse can be observed for both injection pressures (Figure 11(b) and (c)), with there being significant velocity levels in the region of 0 to $5 \mathrm{~mm}$ for both cases. The plume shapes for the two injection pressures tested can also be seen to be similar, although their magnitude was different. When both sprays entered the region of collapsed spray, the higher injection pressure (20 MPa) was found to result in a smaller mean droplet diameter. Also, at $25 \mathrm{~mm}$ vertical distance (during spray collapse) the peak plume direction velocity of the $20 \mathrm{MPa}$ injection pressure case was reduced in comparison to the formed spray at $15 \mathrm{~mm}$, although it did remain greater than the $10 \mathrm{MPa}$ injection pressure case.

\subsection{The influence of hole diameter on injector spray characteristics}

The hole diameter of GDI injector is a very important geometrical parameter which significantly affects the spray characteristics (e.g. droplet size, fuel flow rate) and there is a requirement for additional insight and understanding of the relationship between the hole size and the resultant spray, in order to support both modelling and design processes. Three different hole diameters were investigated in this study, using an injector with holes of converging cross-sectional area, under both atmospheric and flash boiling backpressure conditions. The study was configured as the general setup listed in Table 1 and the specific configuration A of Table 2 for the atmospheric tests and configuration $\mathrm{B}$ for the flash boiling tests. PDA measurements were again gathered across the spray plumes, capturing droplet size and velocity information.

The processed PDA results from the investigation are presented in Figure 12, showing the mean droplet diameter and mean velocities at $40 \mathrm{~mm}$ vertical distance from the nozzle in the vertical direction across the spray plumes of the three injector holes under atmospheric backpressure, $293 \mathrm{~K}$ air temperature. It is apparent that under atmospheric conditions a smaller length to diameter ratio (larger hole diameter) led to a higher mean droplet size. This observation is consistent with findings in the literature [53]. 


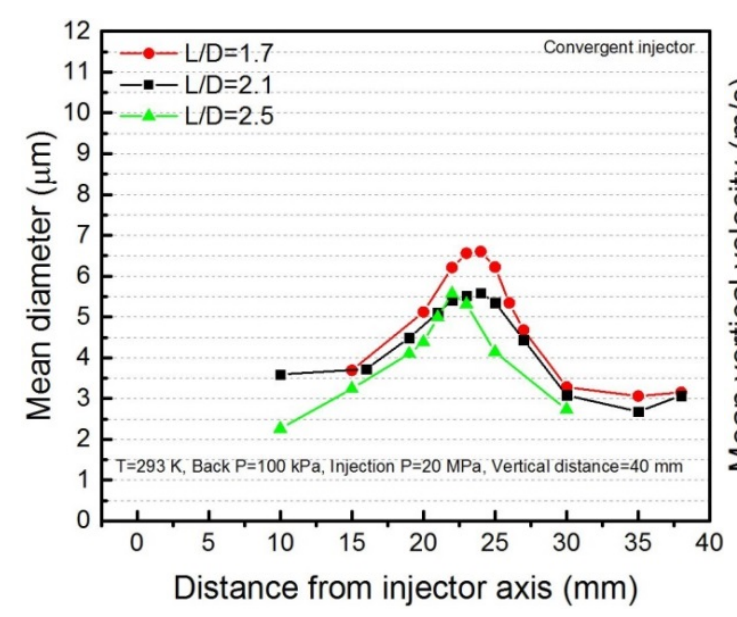

(a)

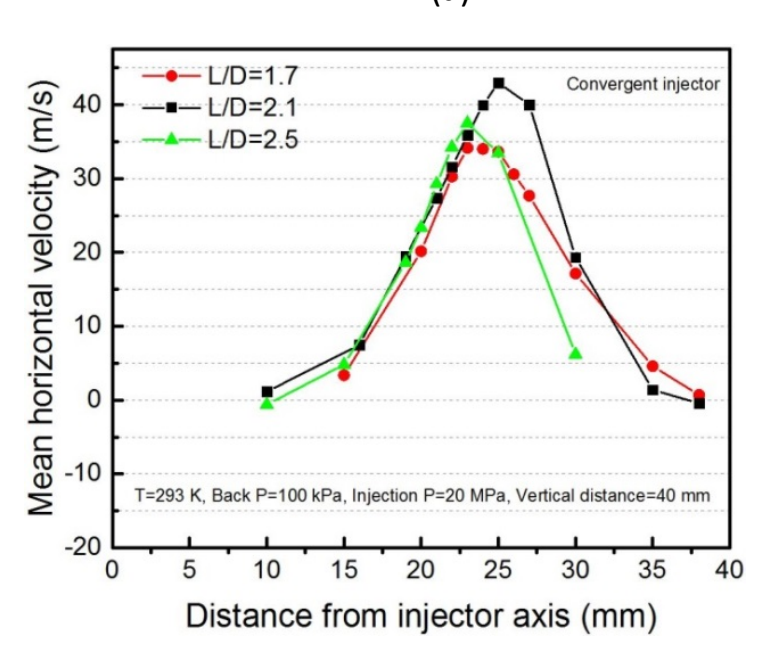

(c)

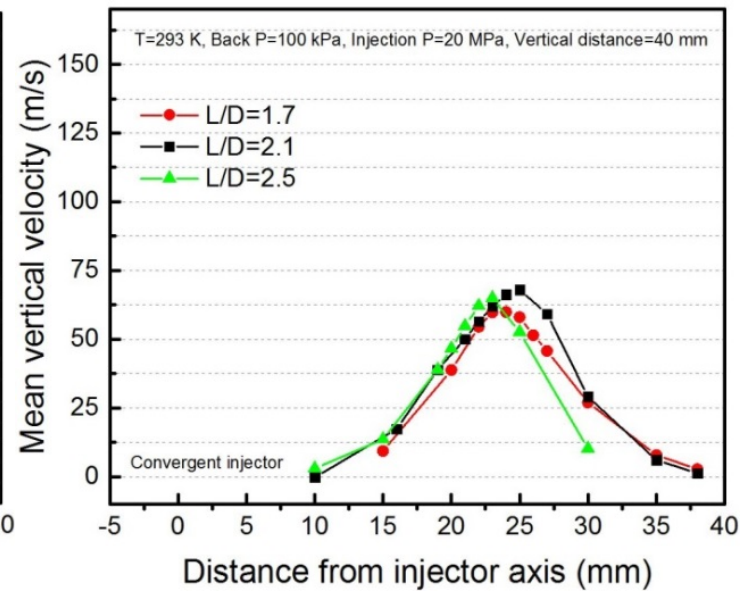

(b)

Figure 12 - Droplet mean diameter (a), mean vertical velocity (b) and mean horizontal velocity for spray under ambient temperature and pressure measured at $40 \mathrm{~mm}$ from injector tip

Figure 13 shows the spray measurements made across the spray plumes under flash boiling conditions, at a distance of $25 \mathrm{~mm}$ from the injector tip. The PDA measurements were made at this position closer to the injector nozzle tip during this test because of the restrictions of the pressure cell used to seal the spray environment. Under the flash boiling conditions, it can be seen from this data that a larger hole diameter again led to a larger average droplet diameter, as observed at ambient conditions in Figure 12.

It can be seen that from Figure 13 (b) and (c) that all three sprays experienced flash boiling and spray collapse at the measurement location $25 \mathrm{~mm}$ downstream of the injector tip, evident from the marked deviation in the vertical velocity signals measured at the spray fringes (between 0 and 5 
$\mathrm{mm})$. The L/D ratio of 2 exhibited a velocity that is markedly greater than for the other two conditions between 0 to approximately $5 \mathrm{~mm}$ distance across the spray region. This might tend to suggest a non-linear relationship between hole L/D ratio and resistance to spray collapse and that the optimum for resistance to collapse for this fuel, injection pressure and set of ambient conditions might lie within the tested range. Likewise, the magnitude of the horizontal velocity component between 0 and $5 \mathrm{~mm}$ was greatest for the $2.1 \mathrm{~L} / \mathrm{D}$ case, indicating this was the region of the most significant inward motion of droplets towards the injector axis.

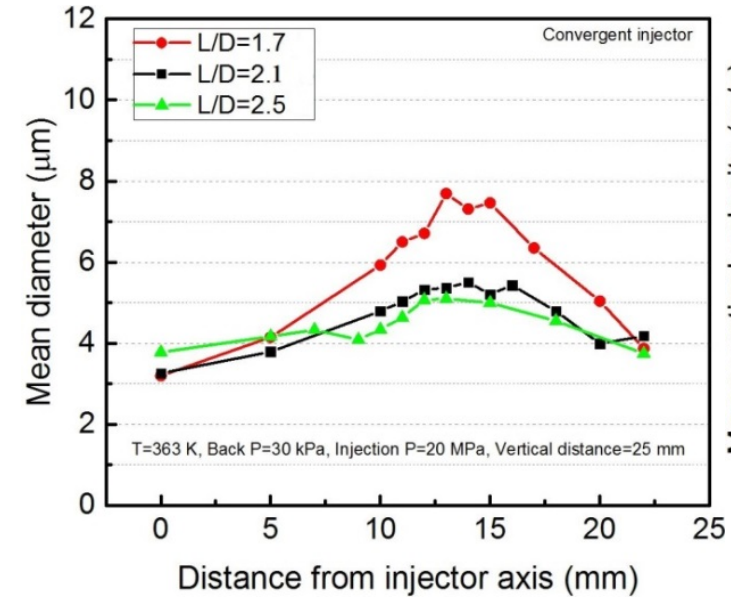

(a)

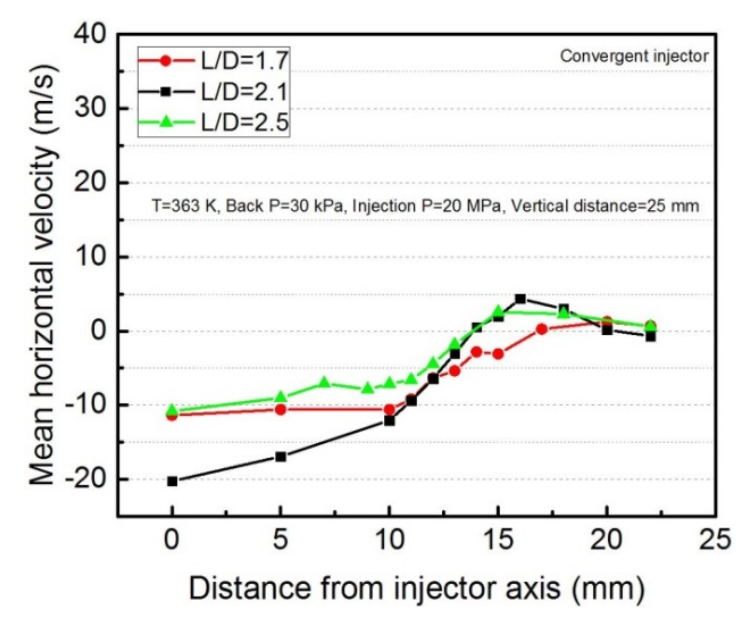

(c)

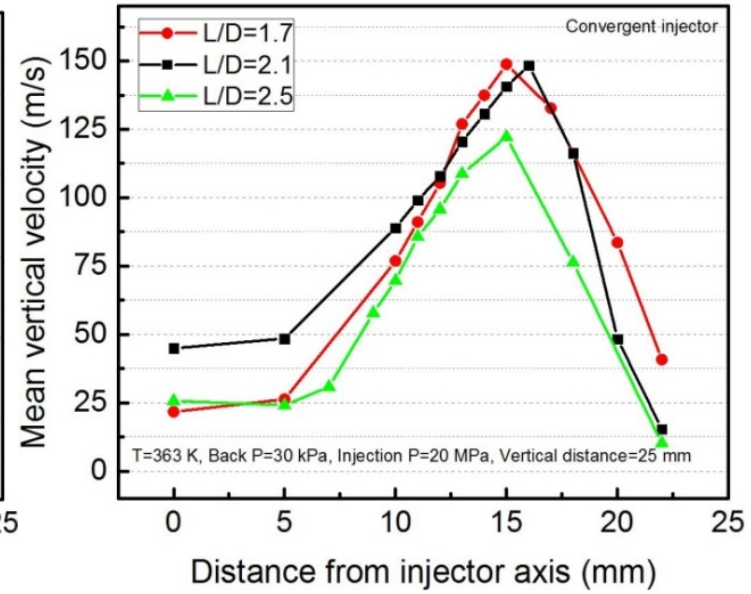

(b)

Figure 13 - Droplet mean diameter (a), mean vertical velocity (b) and mean horizontal velocity for spray under flash boiling conditions measured at $25 \mathrm{~mm}$ from the injector tip 


\section{Conclusions}

In this study, PDA measurements were performed on two 3-hole GDI injectors with different hole diameters and cross-sectional profiles under both atmospheric and flash boiling conditions. The effects of injector design features and injection pressure on spray morphology, droplet size and velocity were investigated. Comparisons of the spray behaviour under atmospheric and flash boiling conditions were made in order to gain a deeper understanding of flash boiling phenomena. The following conclusions were drawn in this investigation:

1. The collected data showed that the spray did not collapse immediately upon exiting the injector holes at the flash boiling conditions tested. In addition, the distance travelled by the spray prior to collapse was increased by increasing the injection pressure.

2. Some of the hole design features were shown to offer greater resistance towards spray collapse than the others when flash boiling. This could lead to changes of orders of spray plume width, droplet size and droplet velocity when shifting from atmospheric conditions to flash boiling conditions. These were as follows:

a. The middle-sized hole of the three diameters tested exhibited the most apparent spray collapse under flash boiling conditions.

b. The divergent hole offered a greater resistance against spray collapse than the convergent hole, with its droplet size affected less by changes in the surrounding conditions, whilst the convergent hole droplet size reduces significantly under flash boiling conditions, creating greater levels of spray collapse.

c. The largest hole diameter created the largest droplets of the three holes and this was maintained as the surrounding conditions were changed to flash boiling conditions. The larger droplet size resulted in a lower level of droplet breakup in comparison to the smaller diameter holes, because of the lower fluid velocity of the large hole. This helped to maintain the spray plume morphology and prevent collapse. 


\section{Acknowledgements}

The authors would like to acknowledge the financial support of the Advanced Propulsion

Centre (APC) for this work which was undertaken as part of TSB/APC project number

113130. The authors also wish to acknowledge Ford Motor Company for their technical support of the work.

\section{References}

[1] Zhao H. Advanced Direct Injection Combustion Engine Technologies and Development. Adv Direct Inject Combust Engine Technol Dev 2010:133-65. doi:10.1533/9781845697327.133.

[2] Zhu R, Hu J, Bao X, He L, Lai Y, Zu L, et al. Tailpipe emissions from gasoline direct injection (GDI) and port fuel injection (PFI) vehicles at both low and high ambient temperatures. Environ Pollut 2016. doi:10.1016/j.envpol.2016.05.066.

[3] Bahreini R, Xue J, Johnson K, Durbin T, Quiros D, Hu S, et al. Characterizing emissions and optical properties of particulate matter from PFI and GDI light-duty gasoline vehicles. J Aerosol Sci 2015;90:144-53. doi:10.1016/j.jaerosci.2015.08.011.

[4] Jiang C, Xu H, Srivastava D, Ma X, Dearn K, Cracknell R, et al. Effect of fuel injector deposit on spray characteristics, gaseous emissions and particulate matter in a gasoline direct injection engine. Appl Energy 2017;203:390-402. doi:10.1016/j.apenergy.2017.06.020.

[5] Zhao F, Lai MC, Harrington DL. Automotive spark-ignited direct-injection gasoline engines. Prog Energy Combust Sci 1999;25:437-562. doi:10.1016/S03601285(99)00004-0.

[6] Wang $\mathrm{C}, \mathrm{Xu} \mathrm{H}$, Herreros JM, Wang J, Cracknell R. Impact of fuel and injection system on particle emissions from a GDI engine. Appl Energy 2014;132:178-91. doi:10.1016/j.apenergy.2014.06.012.

[7] Rodríguez-Antón LM, Gutíerrez-Martín F, Doce Y. Physical properties of gasoline, isobutanol and ETBE binary blends in comparison with gasoline ethanol blends. Fuel 2016;166:73-8. doi:10.1016/j.fuel.2015.10.106.

[8] Krämer M, Kull E, Heldmann M, Wensing M. Investigations on Gasoline Spray Propagation Behaviour Characteristic for Multihole Injectors. SAE Tech Pap 2014-012732 2014. doi:10.4271/2014-01-2732.Copyright.

[9] Khan MM, Hélie J, Gorokhovski M, Sheikh NA. Experimental and numerical study of flash boiling in gasoline direct injection sprays. Appl Therm Eng 2017;123:377-89. doi:10.1016/j.applthermaleng.2017.05.102. 
[10] Guo H, Ma X, Li Y, Liang S, Wang Z, Xu H, et al. Effect of flash boiling on microscopic and macroscopic spray characteristics in optical GDI engine. Fuel 2017;190:79-89. doi:10.1016/j.fuel.2016.11.043.

[11] Guo H, Ding H, Li Y, Ma X, Wang Z, Xu H, et al. Comparison of spray collapses at elevated ambient pressure and flash boiling conditions using multi-hole gasoline direct injector. Fuel 2017;199:125-34. doi:10.1016/j.fuel.2017.02.071.

[12] Schulz F, Beyrau F. The influence of flash-boiling on spray-targeting and fuel film formation. Fuel 2017;208:587-94. doi:10.1016/j.fuel.2017.07.047.

[13] Sher E, Bar-Kohany T, Rashkovan A. Flash-boiling atomization. Prog Energy Combust Sci 2008;34:417-39. doi:10.1016/j.pecs.2007.05.001.

[14] Chen $Y$, Zhang Z. Mechanism of flash boiling and spray analysis with gasoline, isooctane, n-pentane and ethanol from a novel heated tip GDI injector. Appl Therm Eng 2017. doi:10.1016/j.applthermaleng.2016.12.101.

[15] Battistoni M, Grimaldi CN. Numerical analysis of injector flow and spray characteristics from diesel injectors using fossil and biodiesel fuels. Appl Energy 2012;97:656-66. doi:10.1016/j.apenergy.2011.11.080.

[16] Lee J, Madabhushi R, Fotache C, Gopalakrishnan S, Schmidt D. Flashing flow of superheated jet fuel. Proc Combust Inst 2009;32 II:3215-22. doi:10.1016/j.proci.2008.06.153.

[17] Khan MM, Helie J, Gorokhovski M, Wood A, Wigley G, Kashdan J, et al. Numerical Analysis of Multihole Gasoline Direct Injection Sprays. 12th Trienn. Int. Conf. Liq. At. Spray Syst., 2012, p. 1-8.

[18] Zeng W, Xu M, Zhang G, Zhang Y, Cleary DJ. Atomization and vaporization for flashboiling multi-hole sprays with alcohol fuels. Fuel 2012;95:287-97. doi:10.1016/j.fuel.2011.08.048.

[19] Li Y, Guo H, Zhou Z, Zhang Z, Ma X, Chen L. Spray morphology transformation of propane, n-hexane and iso-octane under flash-boiling conditions. Fuel 2019;236:67785. doi:10.1016/j.fuel.2018.08.160.

[20] Li Y, Guo H, Ma X, Wang J, Xu H. Droplet dynamics of di spray from sub-atmospheric to elevated ambient pressure. Fuel 2016;179:25-35. doi:10.1016/j.fuel.2016.03.047.

[21] Pipitone E, Beccari A, Beccari S. Sae technical paper series 2007-24-0052 2007.

[22] He Z, Shao Z, Wang Q, Zhong W, Tao X. Experimental study of cavitating flow inside vertical multi-hole nozzles with different length-diameter ratios using diesel and biodiesel. Exp Therm Fluid Sci 2015;60:252-62.

doi:10.1016/j.expthermflusci.2014.09.015.

[23] Ohrn, T.R., Senser, D.W., Lefebvre AH. Geometrical effects on discharge coefficients for pain-orifice atomizers. At Sprays 1991;1:137-53. doi:10.1615/AtomizSpr.v1.i2.10.

[24] Koo JY, Hong ST. Influence of Fuel Injector Nozzle Geometry on Internal and External 
Flow Characteristics International Congress \& Exposition. SAE Tech Pap Ser 1997.

[25] Guo H, Wang B, Li Y, Xu H, Wu Z. Characterizing external flashing jet from single-hole GDI injector. Int J Heat Mass Transf 2018;121:924-32.

doi:10.1016/j.ijheatmasstransfer.2018.01.042.

[26] Yildiz, D., Rambaud, P., Van Beeck, J. and Buchlin JM. Evolution of the spray characteristics in superheated liquid jet atomization in function of initial flow conditions, In 10th International Conference on Liquid Atomization and Spray Systems, Kyoto, Japan.; 2006.

[27] Vu, H. and Aguilar G. High-speed internal nozzle flow visualization of flashing jets, In 11th Triennial International Annual Conference on Liquid Atomization and Spray Systems, Vail, Colorado, USA.; 2009.

[28] Wang Z, Li Y, Guo H, Wang C, Xu H. Microscopic and macroscopic characterization of spray impingement under flash boiling conditions with the application of split injection strategy. Fuel 2018;212:315-25. doi:10.1016/j.fuel.2017.10.028.

[29] Wang Z, Wang B, Jiang C, Xu H, Badawy T. Microscopic characterization of isooctane spray in the near field under flash boiling condition. Appl Energy 2016;180:598-606. doi:10.1016/j.apenergy.2016.07.115.

[30] Wang B, Wang Z, Bao X, Li Y, Jiang Y, Xu H, et al. Microscopic investigation of nearfield spray characteristics of 2-methylfuran, ethanol and isooctane under flash boiling conditions. Fuel 2018;215:142-52. doi:10.1016/j.fuel.2017.10.035.

[31] Li Y, Guo H, Ma X, Qi Y, Wang Z, Xu H, et al. Morphology analysis on multi-jet flashboiling sprays under wide ambient pressures. Fuel 2018;211:38-47. doi:10.1016/j.fuel.2017.08.082.

[32] Huang Y, Huang S, Huang R, Hong G. Spray and evaporation characteristics of ethanol and gasoline direct injection in non-evaporating, transition and flash-boiling conditions. Energy Convers Manag 2016;108:68-77. doi:10.1016/j.enconman.2015.10.081.

[33] Liu Y, Pei Y, Peng Z, Qin J, Zhang Y, Ren Y, et al. Spray development and droplet characteristics of high temperature single-hole gasoline spray. Fuel 2017;191:97-105. doi:10.1016/j.fuel.2016.11.068.

[34] Wang Z, Jiang C, Xu H, Badawy T, Wang B, Jiang Y. The influence of flash boiling conditions on spray characteristics with closely coupled split injection strategy. Appl Energy 2017;187:523-33. doi:10.1016/j.apenergy.2016.11.089.

[35] Chan QN, Bao Y, Kook S. Effects of injection pressure on the structural transformation of flash-boiling sprays of gasoline and ethanol in a spark-ignition direct-injection (SIDI) engine. Fuel 2014;130:228-40. doi:10.1016/j.fuel.2014.04.015.

[36] Wu S, Xu M, Hung DLS, Pan H. Effects of nozzle configuration on internal flow and primary jet breakup of flash boiling fuel sprays. Int J Heat Mass Transf 2017;110:7308. doi:10.1016/j.ijheatmasstransfer.2017.03.073. 
[37] Wang Z, Badawy T, Wang B, Jiang Y, Xu H. Experimental characterization of closely coupled split isooctane sprays under flash boiling conditions. Appl Energy 2017;193:199-209. doi:10.1016/j.apenergy.2017.02.009.

[38] Araneo L, Donde' R. Flash boiling in a multihole G-DI injector - Effects of the fuel distillation curve. Fuel 2017;191:500-10. doi:10.1016/j.fuel.2016.11.104.

[39] Lacey J, Poursadegh F, Brear MJ, Gordon R, Petersen P, Lakey C, et al. Generalizing the behavior of flash-boiling, plume interaction and spray collapse for multi-hole, direct injection. Fuel 2017;200:345-56. doi:10.1016/j.fuel.2017.03.057.

[40] Wang Z, Ma X, Jiang Y, Li Y, Xu H. Influence of deposit on spray behaviour under flash boiling condition with the application of closely coupled split injection strategy. Fuel 2017;190:67-78. doi:10.1016/j.fuel.2016.11.012.

[41] Yang J, Dong X, Wu Q, Xu M. Influence of flash boiling spray on the combustion characteristics of a spark-ignition direct-injection optical engine under cold start. Combust Flame 2018;188:66-76. doi:10.1016/j.combustflame.2017.09.019.

[42] Wu S, Xu M, Hung DLS, Pan H. In-nozzle flow investigation of flash boiling fuel sprays. Appl Therm Eng 2017;117:644-51. doi:10.1016/j.applthermaleng.2016.12.105.

[43] Tian G, Li H, Xu H, Li Y, Raj SM. Spray Characteristics Study of DMF Using Phase Doppler Particle Analyzer. SAE Int J Passeng Cars - Mech Syst 2010;3:2010-01-1505. doi:10.4271/2010-01-1505.

[44] Wigley G, Hargrave GK, Heath J. A High Power, High Resolution LDA/PDA System Applied to Gasoline Direct Injection Sprays. Part Part Syst Charact 1999;16:11-9. doi:10.1002/(SICI)1521-4117(199905)16:1<11::AID-PPSC11>3.0.CO;2-I.

[45] Wigley G, Heath J, Pitcher G, Whybrew a, Engineering A, Engineering L. Experimental Analysis of the Response of a PDA System to a Partially Atomized Spray.

Measurement 2001;18:169-78.

[46] Jiang C, Parker MC, Spencer A, Wigley G, Garner CP, Helie J. Droplet Size Development in a DISI Injector Fuel Spray. Proc. 18th Int. Symp. Appl. Laser Imaging Tech. to Fluid Mech., 2016.

[47] Mojtabi M, Wigley G, Jedelsky J, Helie J. A Comparison between One and Two Component Velocity and Size Measurements in a Dense Spray. ILASS - Eur 2010, 23rd Annu Conf Liq At Spray Syst 2010:1-8.

[48] Wood A, Wigley G, Helie J. Flash Boiling Sprays produced by a 6-hole GDI Injector. 17th Int Symp Appl Laser Tech to Fluid Mech 2014;i:7-10. doi:10.13140/2.1.5105.3445.

[49] A. Wood, G. Wigley JH. Analysis of Multi-hole GDI Injectors under Flash Boiling Conditions. A. Wood, G. Wigley, J. Helie, 2013.

[50] Chausserie-Laprée P, Hélie J, Chesnel J, Demoulin F-X. Large eddy simulations of atomisation and sprays: application to a high pressure multihole injector. Proc ILASS- 
Europe 2017 28th Conf Liq At Spray Syst 2017. doi:10.4995/ILASS2017.2017.4987.

[51] Mojtabi M, Wigley G, Helie J. The effect of flash boiling on the atomization performance of gasoline direct injection multistream injectors. At Sprays 2014;24:467-93. doi:10.1615/AtomizSpr.2014008296.

[52] Hoffmann G, Befrui B, Berndorfer A, Piock WF, Varble DL. Fuel System Pressure Increase for Enhanced Performance of GDi Multi-Hole Injection Systems. SAE Int J Engines 2014;7:2014-01-1209. doi:10.4271/2014-01-1209.

[53] Technical SAE, Series P. Sae technical paper series 2006-01-0055. SAE Trans 2009;2006. 